\title{
Alternative binders for concrete: opportunities and challenges
}

\author{
Marijana Serdar \\ Dubravka Bjegović \\ Nina Štirmer \\ Ivana Banjad Pečur
}

Marijana Serdar, Dubravka Bjegović, Nina Štirmer, Ivana Banjad Pečur

University of Zagreb, Faculty of Civil Engineering,

Department of Materials, Croatia

Corresponding author: Marijana Serdar, mserdardagrad.hr

https://doi.org/10.5592/CO/FTCE.2019.09 


\section{Alternative binders for concrete: opportunities and challenges}

\section{Abstract}

Rapid population growth and urbanisation has entailed a strong motivation to develop more sustainable construction solutions in line with the $7^{\text {th }}$ basic requirement for construction works - sustainable use of natural resources. One of the strategies is to use materials available in abundant quantities as partial replacement for cement, or to create alternative binders for concrete. The aim of the paper is to provide an overview of the current state of the art in the field of alternative binders for concrete, and to point to the opportunities and challenges for their more systematic application in engineering practice. The state of the art review is connected to scientific projects currently undertaken at the Department of Materials, Faculty of Civil Engineering University of Zagreb, Croatia.

Key words: sustainability, durability, alternative binders, international cooperation, microstructure

\section{Alternativna veziva za beton: prilike i izazovi}

\section{Sažetak}

Brz rast stanovništva i urbanizacija doveli su do snažne motivacije za razvojem održivijih građevinskih rješenja u skladu sa sedmim bitnim zahtjevom za građevine - održivo korištenje prirodnih resursa. Jedna od strategija je korištenje lokalno dostupnih materijala kao djelomične zamjene za cement, ili za izradu alternativnih veziva za beton. Cilj rada je pružiti pregled sadašnjeg stanja u području alternativnih veziva za beton i upozoriti na prilike i izazove za njihovu sustavniju primjenu u inženjerskoj praksi. Pregled stanja u tom području povezan je sa znanstvenim projektima koji se upravo provode u Zavodu za materijale na Građevinskom fakultetu Sveučilišta u Zagrebu, Hrvatska.

Ključne riječi: održivost, trajnost, alternativna veziva, međunarodna suradnja, mikrostruktura 


\section{Introduction}

Concrete is the world's most used construction material (and, in general, the second most frequently used material after water), with over 25 billion tons of concrete used worldwide each year [I].Traditional concrete industry is based on the linear model, i.e. large amounts of non-renewable resources are utilised during production, and significant emissions are caused. In addition, at the end of service life, considerable energy is used for demolition, with generation of waste and further emissions. The global population is expected to reach between 8.3 and 10.9 billion by 2050.This rapid population growth generates an increased demand for clean water, air, land, housing, and infrastructure. To meet the growing needs for urbanisation and to comply at the same time with European goals for the protection of natural resources and reduction of emissions, there is a strong motivation to develop more sustainable construction solutions with a lower environmental impact, in line with the $7^{\text {th }}$ basic requirement for construction works - sustainable use of natural resources [2].

Alternative materials that can be used in sustainable concrete structures are predominantly industrial by-products in the form of finely crushed material added as a partial replacement to cement, with the aim of improving particular properties and/or creating some special properties. Some of these materials, such as fly ash, arc furnace slag, silica dust, and metakaolin, have been used for years either as cement additives or as substitutes for cement. Their usage is made possible by regulations and standards, such as EN 15167-1:2006 Ground granulated blast furnace slag for use in concrete, mortar and grout, EN 13263-I:2005+A I:2009 Silica fume for concrete, EN 450I:20 I 2 Fly ash for concrete. Some alternative materials have recently been introduced, such as sludge from waste water and rice husk ash, while some are still being researched such as the ash from biomass, slag from copper and zinc, red mud, waste from the production of ferronickel, sludge from paper production, phosphor-gypsum, casting sand, and sludge from scrap stone. Recycled aggregate can be produced from some types of construction waste by crushing and sorting particles into desired sizes $[3,4]$. Recycled materials have been increasingly used with the aim of reducing the use of natural aggregates. Some European countries, e.g. the Netherlands, Belgium and Denmark, recycle more than $80 \%$ of the total construction waste resulting from demolition. Even industrial fibres in fibre reinforced concrete can be replaced with more sustainable alternatives, such as natural and recycled fibres [5,6]. An exhaustive overview of many possible alternative materials that can be used in concrete is presented in Figure I [7].

Cement alone contributes to approximately $96 \%$ of the carbon footprint of concrete, and $85 \%$ of the embodied energy [8]. In 2015, the total mass of cement produced was 4,6 billion tonnes [9], [10]. This is equivalent to about $626 \mathrm{~kg}$ of cement/per capita, a value higher than the amount of human food consumption [I I]. The global average $\mathrm{CO}_{2}$ emission per tonne of cement manufactured is estimated at approximately 0.83 tonnes [12], meaning that the production of ordinary Portland cement accounts for $5 \%$ of the world-wide $\mathrm{CO}_{2}$ emission. In case the construction industry continues with 


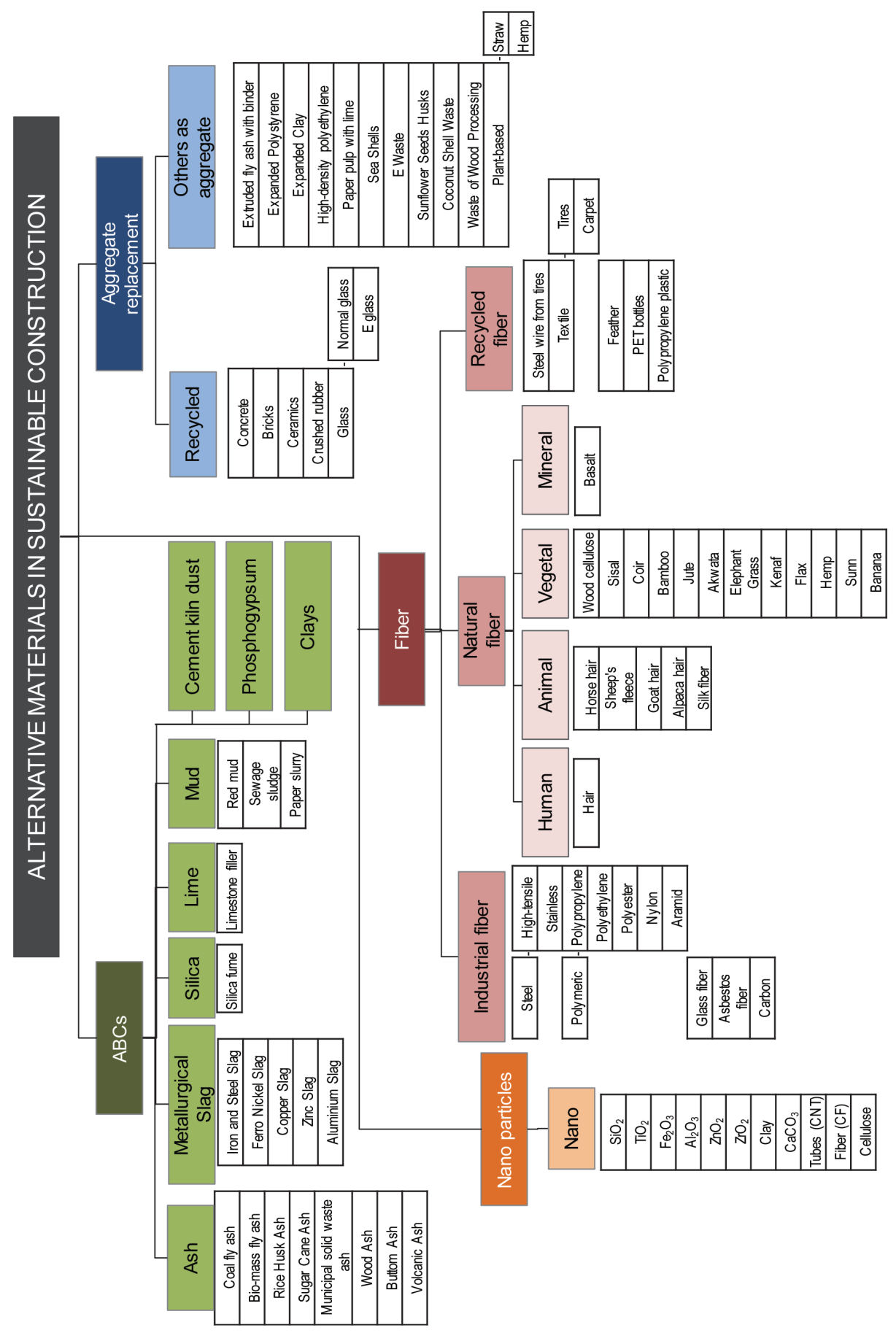

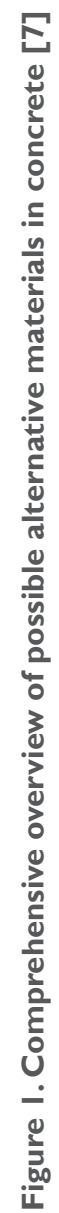


"business as usual", considering the expected increase in production, in 2050 cement industry alone will contribute to $24 \%$ of the total global $\mathrm{CO}_{2}$ emission [13]. Such high share of $\mathrm{CO}_{2}$ emission for just one industry will not be tolerated in the light of international activity to stabilise atmospheric pollution.

Considering that any improvement in cement, due to its dominant share in carbon footprint, can lead to significant savings, most scientific efforts are presently focussing on the development of alternative binders for concrete (ABC). Many types of cement are already available on the market, especially when one considers that there is a limited combination of materials that are used in industrial production of cement. At the same time, the potential of using numerous other materials as partial or total cement replacement is studied, which could lead to creation of an enormous number of new binders that could at some point become available on the market. These new binders could significantly differ from classical cement, and could lead to different concrete properties on the macro scale. It is therefore of paramount importance to adopt a systematic approach when considering new binders, and to critically review opportunities but also challenges these new binders could bring to the engineering sector.

\section{Potential alternative binders for concrete}

Alternative binders for concrete form a new generation of construction materials that constitute a sustainable and economical alternative to ordinary Portland cement. Considering the vast societal challenges and huge amount of material at stake, it is obvious that there is no single solution to this problem and that all research knowledge must be mobilised. The list of potential $A B C s$ is steadily growing, but some of the most promising candidates are listed below.

High volume supplementary cementitious materials (SCM)

Cement containing small amount of supplementary cementitious materials already makes up a large majority of currently produced cementitious binders. The global clinker factor was estimated at 0.77 in 2015, which means that at least $800 \mathrm{Mt}$ of SCMs was used on a total of 4200 Mt cement produced in that year [ 14]. To create a more significant ecological effect, a push toward high-volume SCMs is inevitable [15], and involves development of binders based on SCMs with small amount of cement used as an activator [16]. To meet a growing demand for cement and concrete, and considering limited supplies of high-quality SCMs, research is focussed on alternative SCMs such as red mud [17], [18], biomass ash [18-20], copper slag, calcined clays [2I], limestone [22], and their engineering combinations [23].The main challenge is to find materials that are available in significant quantities and that have favourable chemical and physical properties (such as particle size distribution presented in Figure 2) for use as mineral addition to cement. 

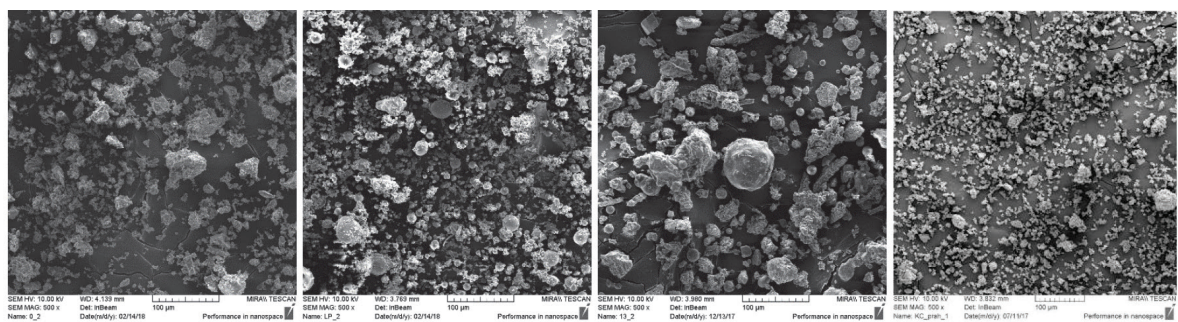

Figure 2. Comparison of size and shape of particles of (from left to rigth) cement, fly ash, biomass ash, and incinirated sewage sludge ash [24]

\section{Limestone calcined clay cement (LCC)}

Limestone is normally used as filler in cement industry; however, in recent years, it started to be used as a partial replacement for ordinary Portland cement [25]. One of the methods of activating reactivity of limestone is by adding reactive and silica-rich and alumina-rich materials, such as calcined clays [2I], [26], [27]. In countries with an established ceramic industry substantial reserves of suitable clays are currently stockpiled as waste [28]. Looking at the map presented in Figure 3 a) it can be observed that the clay most favourable for application in binder (kaolinite) is abundant mostly in regions where there is a massive need for construction, which makes the idea of unleashing this clay use potential highly justified. Currently, research efforts are focussed on pinpointing types of clays whose calcination would yield the most reactive material with an acceptable ecological footprint. This is precisely the primary aim of the Swiss-Croatian collaborative project ACT. Reserves of clay available as waste in the region of Topusko in Croatia are shown in Figure $3 \mathrm{~b}$ ).

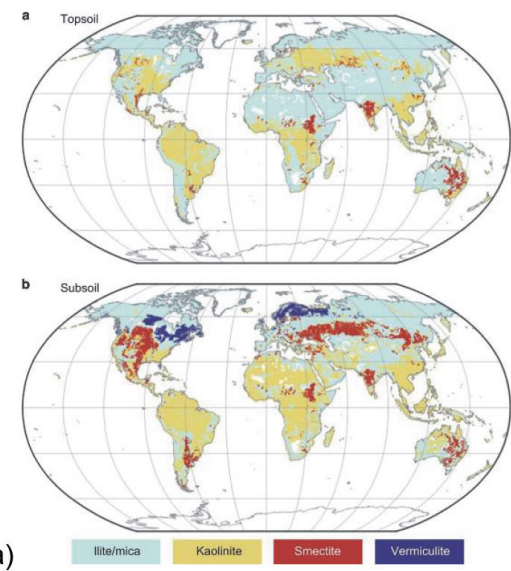

b)

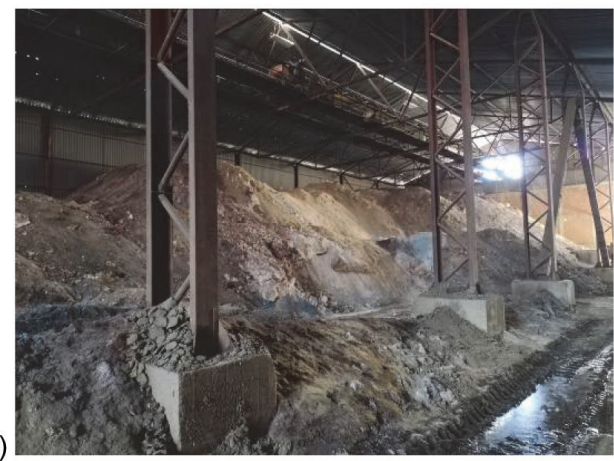

Figure 3.a) Distribution of the most abundant clay-size mineral group in each grid cell around the world, nicely coinciding with the parts of the world in need of massive construction [29]; b) Stockpiling of clay in Topusko, Croatia 


\section{Alkali activated materials (AAM)}

Alkali activated materials can be any binder system derived by reaction of an alkali metal source (activator) with a solid silicate powder (precursor) [30], such as fly ash and slag [3 I], ferronickel slag [32], red mud [33], calcined clay [34], etc. The activators are soluble substances that supply alkali metal cations, raise $\mathrm{pH}$ in the mixture, and accelerate dissolution of solid precursor. Figure 4 shows an example of compressive strength testing for concrete prepared with $370 \mathrm{~kg}$ of CEM I per one cubic meter of concrete and 0.42 water to cement ratio, on the one side, and with mix of $340 \mathrm{~kg}$ of fly ash and $85 \mathrm{~kg}$ of slag per one cubic meter of concrete activated with water glass and $\mathrm{NaOH}$. Considering that the second mix is truly cement free, the compressive strength result of over $50 \mathrm{~N} / \mathrm{mm}^{2}$ is quite remarkable. Challenges in the field of AAM use lie in the fact that activators are industrially produced chemicals, and therefore do require special attention during handling. Thus, the quantity of activators needed to obtain satisfactory properties of resulting concrete should be minimised.Another challenge lies in the fact that currently the most developed AAM are based on fly ash and slag. It is generally accepted that, on the global scale, the quantities of these materials are insufficient to fully substitute total cement consumption with AAM. Therefore, AAM will probably hold only a percentage of the market of sustainable construction materials in the future.
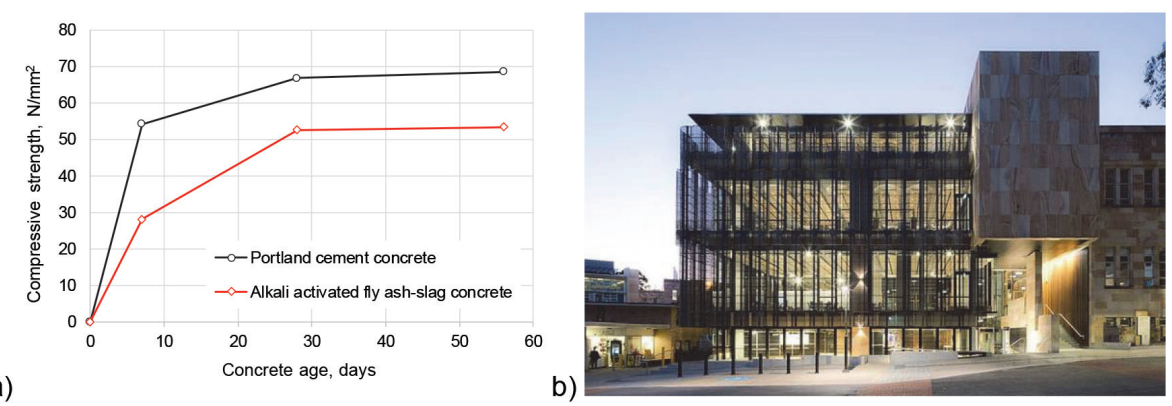

Figure 4. a) Compressive strength of OPC and alkali-activated fly ash-slag concrete [35]; b) Queensland's University GCl building with 3 suspended floors made of geopolymer concrete [36]

\section{Calcium sulphoaluminate cement (CSA)}

Calcium sulphoaluminates are based on two types of clinkers: sulphoaluminate belite clinker and ferroaluminate clinker [37], [38], in which different amounts of calcium sulphate are added [39]. CSA cements are based on three raw materials - limestone, bauxite and calcium sulphate, and current research efforts are focussing on replacing some of these materials with industrial waste and by-products. Materials of special interest are fly ash [40], blast furnace slag, phosphogypsum, electric arc furnace slag, red mud, and flue gas desulphurisation gypsum, etc. CSA cements have very fast reaction time (Figure 5 a), leading to fast strength gain, which makes them ideal for application where load bearing capacity in early ages is needed, such as airport runways (Figure 5 b). 

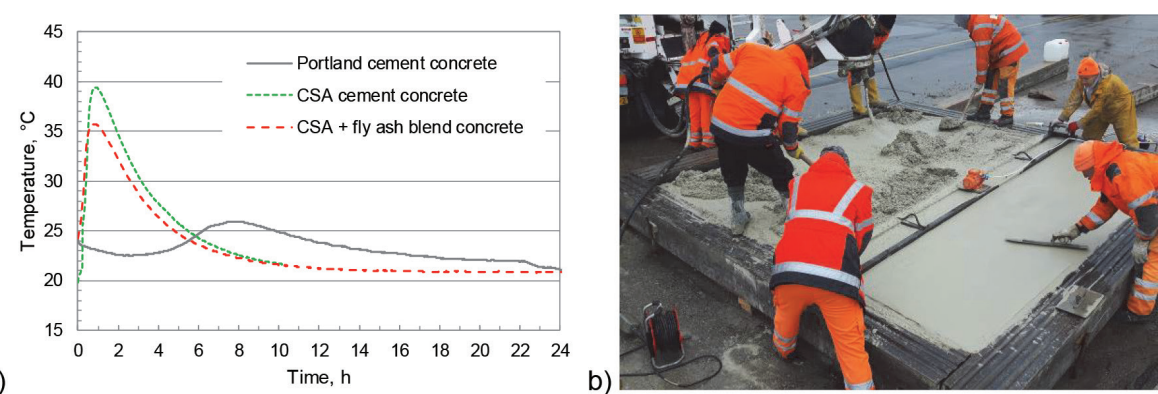

Figure 5.a) Comparison of temperature development of Portland cement concrete, CSA cement concrete, and CSA and fly ash blend concrete during 24 hours [4I]; b) Placement of CSA cement based concrete on airport runway (photo curtesy:T. Conjar,TPA)

\section{Opportunities -raw materials available in Southeast Europe}

To be used in a binder, a raw material needs to have properties that are comparable to cement properties, such as particle size distribution, chemical composition and solubility / stability in water. Since cement is basically composed of silicon, aluminium, iron, calcium, sodium, potassium and magnesium oxides, it is raw materials based on these oxides, with a potential to form hydrates with cementing properties, that are of interest. When looking for potential sources, it becomes obvious that there are numerous industries that create by-products exhibiting exactly these properties. Figure 6 shows a selection of some of these materials.

As a first step in the development of $A B C$ with regional materials, appropriate sources must be identified. The first estimate of availability of relevant secondary raw materials in the region is presented in Table I.The overview given in Table I provides the starting point for identification of currently available suitable waste materials and their estimated quantitates generated each year.

The locally identified materials currently present environmental burden for the named industries, since they are mostly landfilled near the plant. These landfills will soon become not only environmental but an economic burden as well. Furthermore, there are many examples of environmental catastrophes resulting from poorly controlled landfilling. A recent example is the spilling of red mud around villages in Hungary [44]. By finding possible uses of industrial waste products as raw materials for preparation of alternative binders for concrete, it is possible to avoid ecological problems (which could lead to environmental disasters) and high landfill costs (which could lead to increase in energy or material costs). Examples of landfilling of raw materials obtained as by-products are presented in Figure 7 a-c, which shows landfilling of slag from steel production, fly ash from a thermal power plant, and red mud from aluminium production. 
Ash

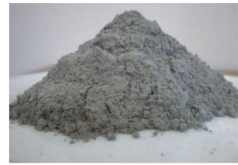

Coal fly ash

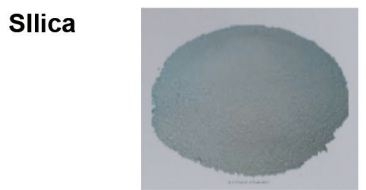

Silica fume

Slag

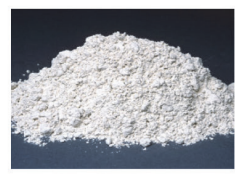

Steel slag

Sludge

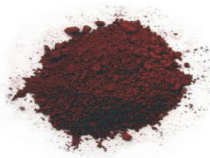

Red mud

Other

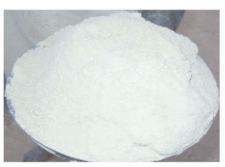

Metakaolin

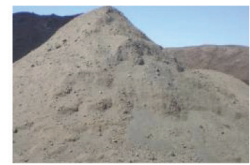

Wood biomass ash

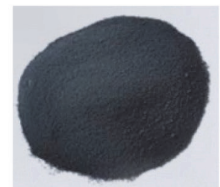

Silica fume

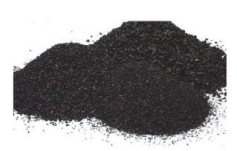

Copper slag

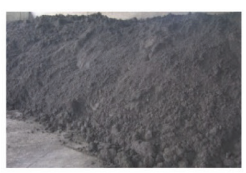

Sewage sludge

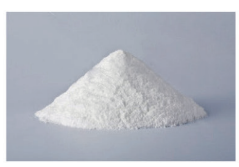

Limestone filler

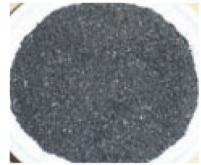

Rice flakes ash

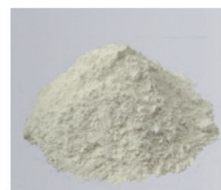

Silica powder

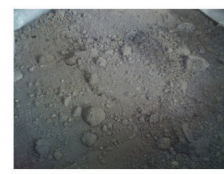

Zinc slag

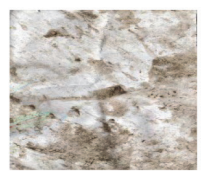

Paper sludge

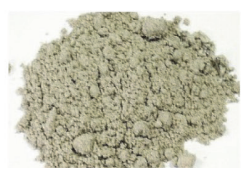

Phosphogypsum

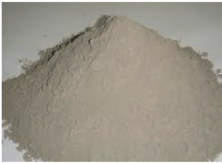

Sugar cane ash

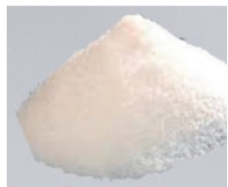

Fumed silica

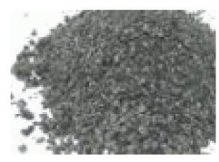

Ferronickel slag

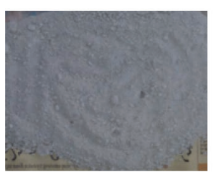

Stone sludge

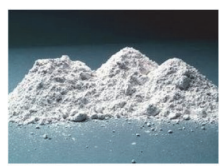

Cement kiln dust

Figure 6.Alternative materials as an addition in cement production or partial cement substitution [42]
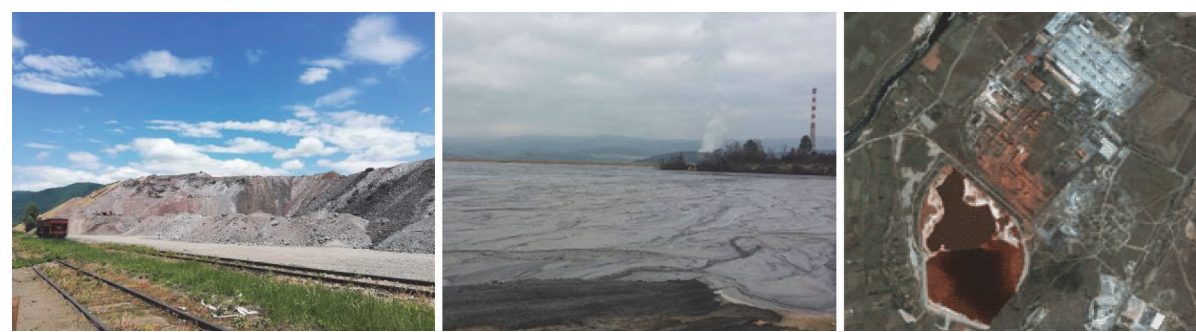

Figure 7. Examples of stockpilling industrial waste materials: a) slag landfill, b) fly ash landfill, c) red mud landfill 
Table I. First estimate of availability of relevant secondary raw materials for $A B C s$ $[7],[43]$

\begin{tabular}{|c|c|c|}
\hline Type & Location & Quantities \\
\hline \multirow{4}{*}{ Fly ash } & Plomin TE, Croatia & 70,000 tons/year \\
\hline & Šoštanj TE, Slovenia & I million tons/year \\
\hline & Nikola Tesla TE, Serbia & 5.5 million tons/year \\
\hline & TE Kakanj and Tuzla, $\mathrm{BiH}$ & 800.000 tons/year \\
\hline GGBS & Zenica, Bosnia \& Herzegovina & 650.000 tons/year \\
\hline BOF slag & Zenica, Bosnia \& Herzegovina & I50.000 tons/year \\
\hline \multirow{3}{*}{$\begin{array}{l}\text { Electric arc furnace steel } \\
\text { (EAFS) slag }\end{array}$} & Jesenice, Slovenia & about $150 \mathrm{~kg} / \mathrm{I}$ ton of steel \\
\hline & Sisak, Croatia & I.5 million tons, landfilled \\
\hline & Split, Croatia & 30,000 tons, landfilled \\
\hline Silica fume & Jajce, Bosnia \& Hercegovina & 10,000 tons/year \\
\hline \multirow{2}{*}{ Red mud } & Dobro selo, B\&H & 10 million tons, landfilled \\
\hline & Podgorica (KAP), Montenegro & 7 million tons, landfilled \\
\hline $\begin{array}{c}\text { Flue gas desulfurization } \\
\text { gypsum }\end{array}$ & Slovenia & 400,000 tons/year \\
\hline Phosphogypsum & Lonja field, Croatia & 300,000 tons landfilled \\
\hline Ferronickel slag & Macedonia & I.I3 million tons/year \\
\hline \multirow{2}{*}{ Copper slag } & Serbia & 23 million tons landfilled \\
\hline & Bulgaria & 700.000 tons/year \\
\hline Wood ash & Croatia & 25.414 tons/year \\
\hline Limestone & Exploitation sites in Croatia & approx. 150 mill. tons reserve \\
\hline Clay & Exploitation sites in Croatia & $\begin{array}{l}\text { approx. } 4 \text { mill tons of } \\
\text { reserve }\end{array}$ \\
\hline
\end{tabular}

\section{Challenges}

\subsection{Moving beyond $10 \%$ of cement replacement - the importance of understanding microstructure}

Many alternatives can be used as an addition or substitution of cement for up to 5 - 10\%, albeit with limited or insignificant influence on concrete properties. However, proper understanding of mechanisms that trigger and control raw material reactivity is of paramount importance for increasing the replacement levels and reaching more significant ecological benefits [14]. It is only by full understanding of pozzolanic reactivity, hydration reaction and type and properties of phases formed during the reaction that we can modify and control in a desirable way the substitution of cement, and reach high or total cement replacement. Because of the relatively limited combination of chemical compositions, it is possible to develop generic approaches to screening these materials and evaluating their potential for use as SCMs. Thus, a 
more rapid and significant leap in knowledge and full-scale application in practice can be obtained. A first step in applying generic approach to the replacement of cement is definitely a detailed chemical and physical characterization of raw materials. An example of such characterization is shown in Figure 8 a) and b), showing particle size distribution and mineralogical composition, respectively, of different types of wood ash. This characterisation was made within the research project "Transformation of ash from wood biomass into resilient construction composites, TAREC 2", funded by the Croatian Science Foundation.
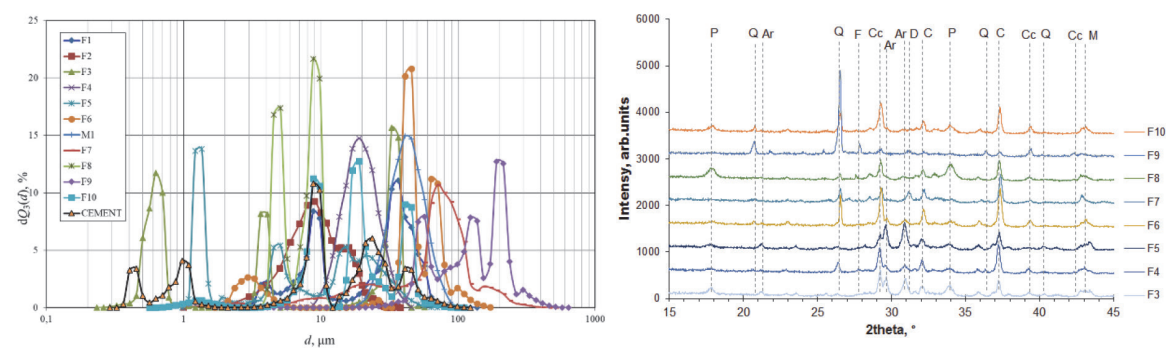

Figure 8 Characterisation of wood biomass fly ash (WBA-F): a) particle (volume)size distribution of WBA-F samples and cement, b) XRD analysis of WBA-F (Cc - calcium carbonate $\mathrm{CaCO}_{3} ; \mathrm{Q}$ - quartz $\mathrm{Si}_{2} \mathrm{O}, \mathrm{C}$ - calcium oxide $\mathrm{CaO}$; $\mathrm{M}$ - periclase $\mathrm{MgO}$; $\mathrm{F}$ - fairchildite $\mathrm{K}_{2} \mathrm{Ca}\left(\mathrm{CO}_{3}\right)_{2} ; \mathrm{Ar}$ - arcanite $\mathrm{K}_{2} \mathrm{SO}_{4} ; \mathrm{P}$ - portlandite $\left(\mathrm{Ca}(\mathrm{OH})_{2}\right)[45]$

Based on a detailed characterization of raw materials a preliminary ranking can be made, which could help researchers to focus further search for potentially reactive raw materials on the most promising candidates. Examples of such ranking can be found in papers by Carević, l. et al. [45].

At the Department of Materials of the Faculty of Civil Engineering, University of Zagreb, the idea of partly replacing cement with materials that have beneficial properties has long been actively pursued [46]. There are years of experience on designing and testing tailored concrete products with alternative additions, some of which resulted in the Intellectual Property Rights protection [47]. However, with the increasing number of possible alternatives in the region, a need for establishing a more in-depth approach to cement replacement based on microstructural testing has been recognised at the Department of Materials.

To adopt such an approach, the Department of Materials of the Faculty of Civil Engineering in Zagreb teamed up with Laboratory of Construction Materials at École polytechnique fédérale de Lausanne in Switzerland, to propose the project entitled "Advanced low $\mathrm{CO}_{2}$ cementitious materials, ACT". Proposals was accepted for funding under the call for Joint Research Project (JRP) "Croatian-Swiss Research Programme CSRP 2017-2023", and the activities on the project started in April 2019. The proposed project aims to optimise the formulation of cements and concretes based on partial replacement of $\mathrm{CO}_{2}$ intensive clinker by locally available waste streams and by-products as supplementary cementitious materials (SCMs). This will 
be done by applying advanced testing techniques available at EPFL and using expert knowledge of Professor Karen Scrivener to fully unlock the potential of regionally available materials, but also to form at the Faculty of Civil Engineering a group of experts in microstructural analysis of cementitious materials. The main activity of the project will be carried out by $2 \mathrm{PhD}$ students, based in Croatia, who will spend about one third of the project time at EPFL, learning about and applying available methods to their materials. In this way, a high level of knowledge transfer from the Swiss group to Croatia will be realised.

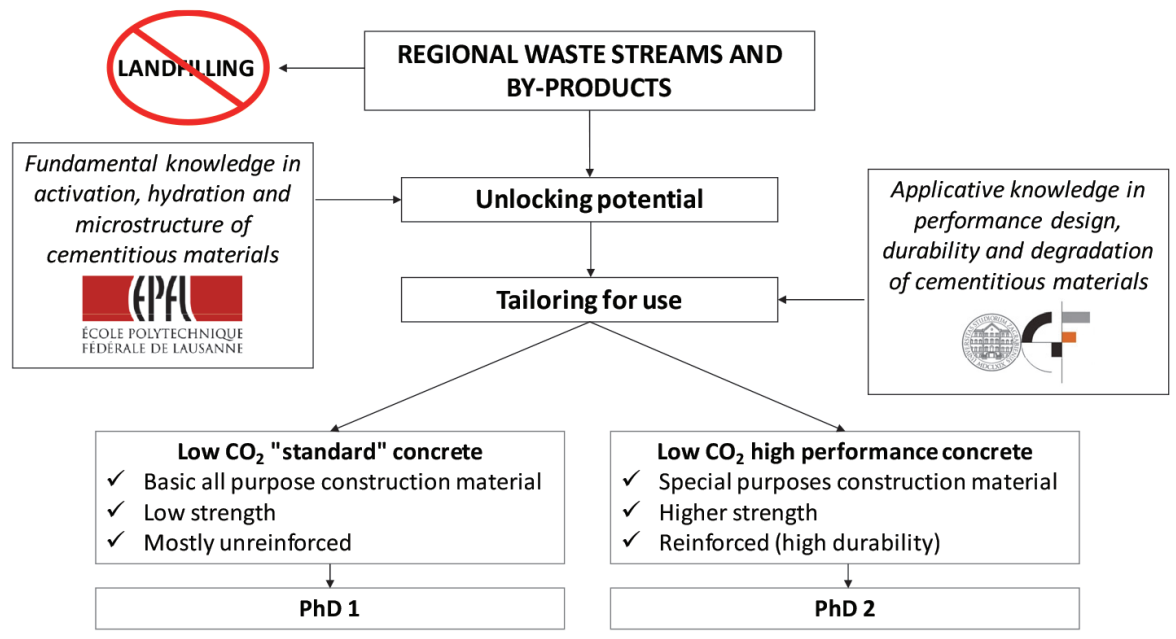

Figure 9.An outline of research plan for the ACT project

\subsection{Application despite the standards - the importance of equivalent performance concept}

Currently, the only standardized procedure for designing concrete mixes to meet environmental exposure requirements is a prescriptive provision given in EN 206I. The deficiency of the prescriptive durability design approach is that durability properties are specified based on requirements for constitutive materials, construction and curing, without prescribing the exact property, testing method and limiting values for specific material properties. No calculation procedure is defined if longer service life is required for example in the case of infrastructures with the requested service life of over 100 years. Compliance procedure for on-site concrete is merely based on the assessment of compressive strength, since it is almost impossible to effectively control most of the prescribed limiting values. But even more problematic issue is the fact that the prescriptive approach ignores the different performance of different cement types. It cannot therefore be used for new materials, e.g. alternative binders for concrete. 
On the contrary, performance-based design is based on durability indicators, which are properties of concrete that can be proven in the laboratory and on-site and, therefore, they can also be used during construction as a part of quality control and on-site compliance control [48]. Durability indicators were prescribed in the Gaženica New Port project and these durability indicators were continuously checked for compliance during construction of the port [49]. The example given in Figure 10 a) shows statistical distribution of chloride migration coefficient values obtained on 53 samples prepared during concreting of reinforced concrete elements. On this project, prescribed chloride migration coefficient values for these elements were in the range of $5-1010^{-12} \mathrm{~m}^{2} / \mathrm{s}$. The figure also shows that the concrete quality is well within the range of prescribed values, and so it can be concluded that the achieved concrete transport property complies with the required concrete transport property.

a)

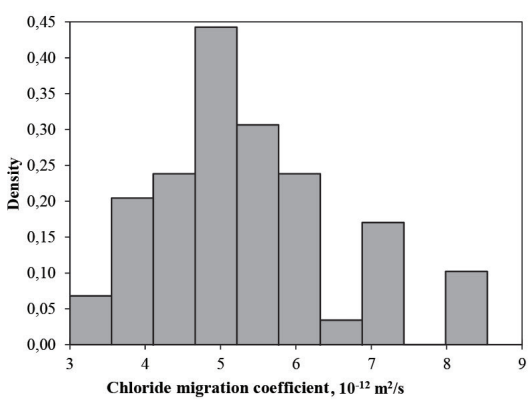

Figure 10.a) Histogram of chloride migration values obtained for a set of concrete samples taken in the scope of the concrete compliance checking procedure during construction of the Gaženica New Port [49], b) New Port of Gaženica during construction, with the city of Zadar in the background

Using performance-based design of concrete structures, instead of merely prescriptive provisions, it would be possible to apply in practice higher substitution of cement with different alternative materials. A step towards this is what is known as the Equivalent Concrete Performance Concept (ECPC) [50]. The ECPC allows amendments to the requirements for minimum cement content and maximum $\mathrm{w} / \mathrm{c}$ ratio when a combination of a specific addition and a specific cement source is used. It shall be proven that the concrete has an equivalent performance especially with respect to its interaction with the environment and to its durability when compared with a reference concrete in accordance with the requirements for the relevant exposure class. For the ECPC to be established in practice, methods to test durability of concrete should be standardised and some property values expected for different environment exposure classes established, which is for now not fully implemented even on the European level for the traditional OPC concrete. Additionally, for the ECPC to work for different alternative binders, it is necessary to ensure that the testing methods, well-established for OPC concrete, deliver realistic results for alternative binders and, furthermore, that they can be used, with a certain level of 
confidence, to judge performance of these materials in real aggressive environments. It is with this aim that Horizon 2020 Marie Skłodowska-Curie Innovative Training Network entitled "PhD Training Network on Durable, Reliable and Sustainable Structures with Alkali-Activated Materials, DuRSAAM" was formed, involving a group of seven European research institutes (Ghent, Delft, Sheffield, Patras, Zagreb, Karsruhe, and ETH Zurich), each of them leader in the field of durability and sustainability of materials and structures [5I]. The project relies on $13 \mathrm{PhD}$ students who will form a group of young professionals with international knowledge and experience in formulating, testing and modelling alkali-activated materials, resilient to exposure to various environmental conditions. An overview of various early-stage research projects (ESR I-I3) is presented in Figure II.The research on two of these projects (ESR 8 and 9) has started at the Department of Materials in Zagreb, while another two (ESR2 and ESR 10) will be co-mentored by the Department of Materials in Zagreb.

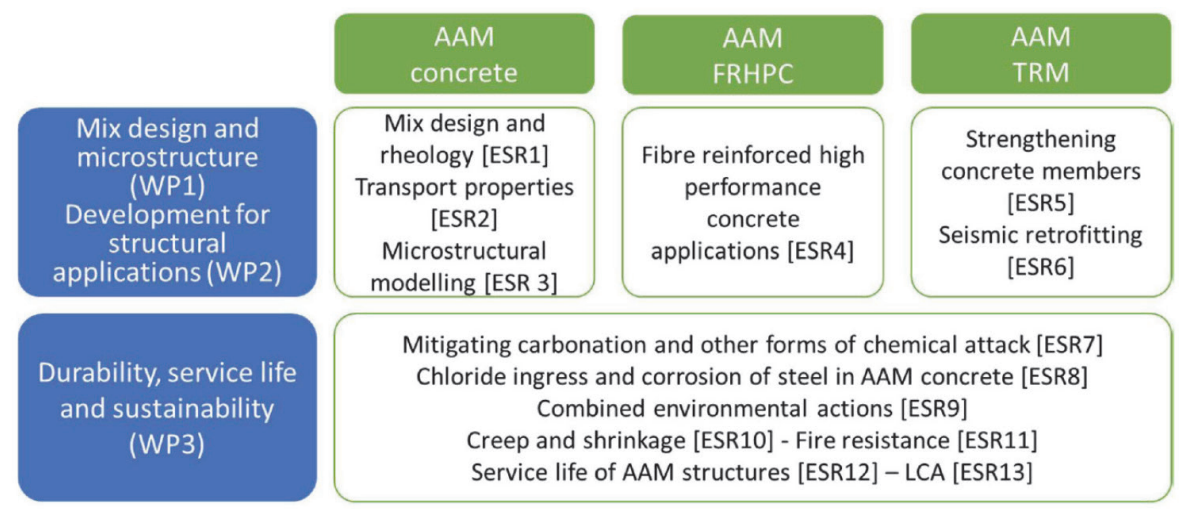

Figure I I. Overview of DuRSAAM activity through I 3 PhD ESR projects [5 I]

\subsection{Long-term durability - how sustainable are alternative binders?}

Alternative binders have various physical (pore structure, tortuosity of pores) and chemical ( $\mathrm{pH}$ of pore solution, composition of hydration products) characteristics compared to ordinary Portland cement. It is therefore a question whether physical and chemical degradation models well-established for OPC can explain microstructural changes of $A B C$ s during exposure to aggressive environment.

A perfect example of this is the carbonation of concrete prepared with $A B C$ s. Carbonation is known to affect the durability of cement-based materials under longterm conditions, since it leads to loss of concrete alkalinity and, subsequently, to an increased susceptibility to reinforcement corrosion in OPC-based concrete. In OPC concrete carbonation mainly causes decalcification of portlandite, and if a sufficient portlandite content is available, the properties of concrete are not strongly affected by carbonation. Conversely, in systems containing little or no portlandite carbonation 
induces decalcification of other hydration products, leading to chemo-mechanical changes inside the concrete, and therefore can affect its porosity, transport and mechanical properties and corrosion of steel [52]. The example given in Figure 12 shows changes of corrosion parameters of steel in non-carbonated concrete after 28 days of curing (Figure 12 a) and in carbonated concrete after I month of carbonation (Figure 12 b). Changes of corrosion parameters are shown for mortars prepared with three types of binders: i) OPC - binder based on Ordinary Portland cement CEM I, b) $\mathrm{IpH}$ - binder based on high volume of fly ash and silica fume, and c) $\mathrm{nSi}$ - binder based on cement with high amount of slag (CEM III/A) with the addition of nano silica. It can be observed that, while in non-carbonated concrete $\mathrm{IpH}$ and $\mathrm{nSi}$ binders provide superior corrosion protection of steel, it is not the case once these mortars are carbonated.
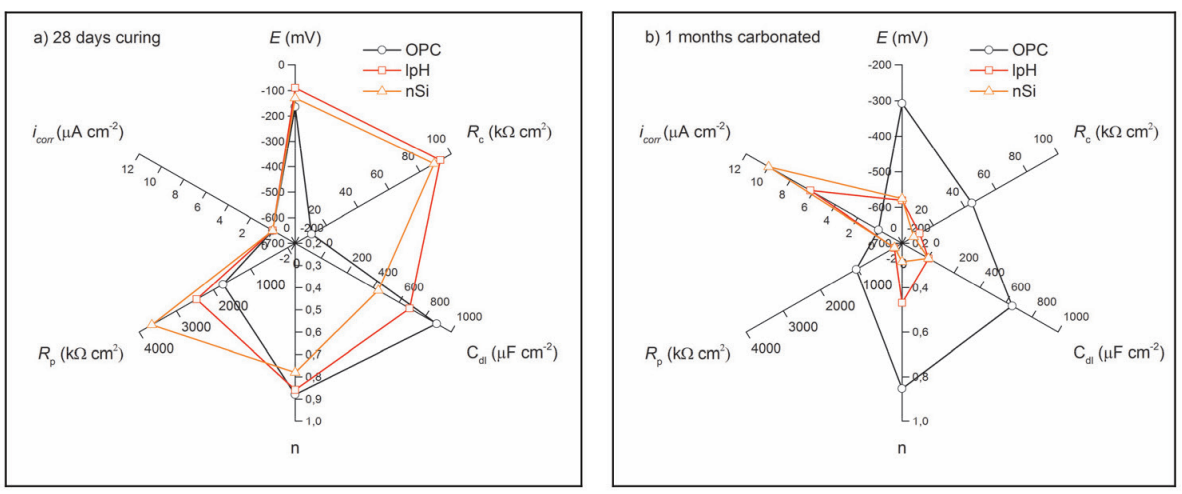

Figure 12. Overview of all corrosion parameters of steel embedded in three different mortars after a) 28 days of curing, b) at the end of the testing period on samples carbonated for I month [52]

Unlike OPC, the experience with alternative binders does not cover the period of more than 50 years, and their long-term behaviour in environment cannot be judged based on exhaustive field tests. It has therefore become obvious that, in order to have some knowledge about their expected behaviour in environment, it is crucial to understand their degradation from nano- and microscopic scale. This is possible only if knowledge and instrumentation are available at the same place. Through the Installation Research Project titled "ALTERNATIVE BINDERS FOR CONCRETE: understanding microstructure to predict durability, $A B C$ ”, proposed and accepted by the Croatian Science Foundation, it is planned to establish a research group as a centre of expertise for multiscale research of durability and microstructure of alternative construction materials, capable to autonomously use advanced analytical techniques provided by regional instrumentation network and trained by international centres of knowledge and excellence in the field. 


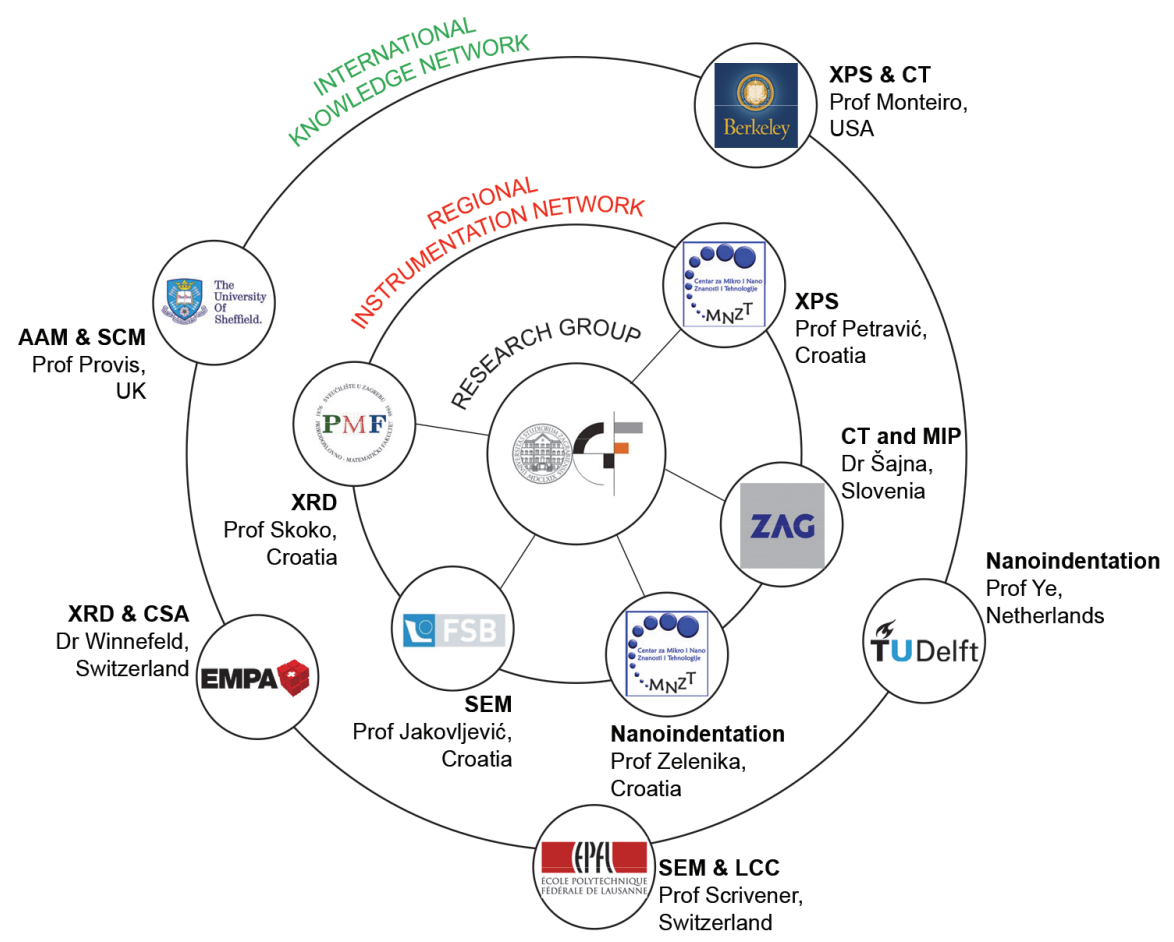

Figure 13. Research network of $A B C$ project comprising research group at Faculty of Civil Engineering, regional instrumentation network, and international knowledge network

\section{Concluding remarks}

The overview presented in this paper clearly shows that there are numerous opportunities in the field of concrete binders that can be used for lowering ecological impact of concrete industry. However, for their greater practical application, several challenges must be addressed in a more systematic way. Some of the main challenges recognised in this paper are: importance of microstructural analysis for higher cement replacement levels, importance of applying performance-based approaches in the design of concrete durability, and importance of durability analysis for alternative materials to ensure their long-term sustainability. These challenges will be dealt with in the following years through projects that are currently undertaken at the Department of Materials, Faculty of Civil Engineering, University of Zagreb, which are funded through national, Swiss and European funds. This includes establishment of a research group and laboratory for an advanced research of sustainable materials. 


\section{Acknowledgements}

Parts of the work presented in this paper were performed in the scope of the following projects: “Advanced Low CO 2 Cementitious Materials, ACT” (No I80590), funded by the Croatian Science Foundation and the Swiss National Science Foundation with funds obtained from the Swiss-Croatian Cooperation Programme, "Transformation of Wood Biomass Ash into Resilient Construction Composites” (IP-2016-06-770I) and "Alternative Binders for Concrete: understanding microstructure to predict durability, ABC" (UIP-05-2017), funded by the Croatian Science Foundation, and "PhD Training Network on Durable, Reliable and Sustainable Structures with AlkaliActivated Materials, DuRSAAM", funded by the European Commission through H2020-MSCA-ITN-20I8.

\section{Author's note}

This paper is based on the manuscript prepared for publication in journal Građevinar. Due to the importance of the topic covered, journal publication was for the purpose of this edition, extended and connected with the research performed at the Faculty of Civil Engineering.

\section{References}

[1] World Business Council for Sustainable Development: Cement Industry Energy and $\mathrm{CO}_{2}$ Performance- Getting the Numbers Right, Geneva, 2009.

[2] Regulation (EU) No 305/20II of the European Parliament and of the Council of 9 March 20 II laying down harmonised conditions for the marketing of construction products and repealing Council Directive 89/106/EEC Text with EEA relevance, Official Journal of the European Union 305 (2011), Pp. 43-88

[3] CONWAS project, LIFE05TCY/CRO/000 I I4.(2006-2008). Development of sustainable construction and demolition waste management system for Croatia, http://www.igh.hr/conwas , 30.07.2019.

[4] Bjegovic, D., Mikulic, D., Stirmer, N.: Proposal for construction and demolition waste management system in Croatia, Life Cycle Assessment applications: results from COST action 530, AENOR ediciones (2009), pp. I58-165

[5] Jain, D., Kothari, A.: Hair Fibre Reinforced Concrete, Research Journal of Recent Sciences I (20II), Pp. I28-133

[6] Baricevic, A., Bjegovic, D., Skazlic, M.: Hybrid Fiber-Reinforced Concrete with Unsorted RecycledTire Steel Fibers, Journal of materials in civil engineering, 29 (2017) 6, doi: 10.106I/(ASCE)MT.19435533.0001906

[7] Bjegović, D., Serdar, M.: Alternative materials in sustainable construction, Proceedings of the $\left.\right|^{\text {st }}$ International Conference CoMS_2017,Zadar, 2017.

[8] Schokker, A. J., Green, U. S., Burg, R. G., Mlutkowski, K. P., Jay, R. M.: The Sustainable Concrete Guide Applications Production, U.S. Green Concrete Council, 2010.

[9] The European Cement Association Cembureau, World Statistical Review 1996-2008: Cement Production, Trade, Consumption Data, Brussels, 2010. 
[10] The European Cement Association Cembureau,Activity Report 20I5., Brussels, 2015.

[II] FAO, Food wastage footprint. Impacts on natural resources - Summary Report, 2013.

[12] Gartner, E. M., Macphee, D. E.:A physico-chemical basis for novel cementitious binders, Cement and Concrete Research, 4 I (20I I) 7, pp. 736-749

[13] Provis, J. L.: Green concrete or red herring? - future of alkali-activated materials, Advances in Applied Ceramics, II3 (20I4) 8, doi: I743676I I4Y.000.

[14] Snellings, R.:Assessing, Understanding and Unlocking Supplementary Cementitious Materials, RILEM Technical Letters, I (2016), pp. 50

[15] Celik, K., Meral, C., Mancio M., Mehta P.K., Monteiro, P.J.M.:A comparative study of self-consolidating concretes incorporating high-volume natural pozzolan or high-volume fly ash, Construction and Building Materials, 67 (2013). doi: I0.1016/j.conbuildmat.2013.1 I.065.

[16] Serdar, M., Biljecki, I., Bjegovic, D.: High-Performance Concrete Incorporating Locally Available Industrial By-Products, Journal of Materials in Civil Engineering, 29 (2017) 3, pp. I-8

[17] Ribeiro, D. V. , Labrincha, J. A., Morelli, M. R.: Effect of the addition of red mud on the corrosion parameters of reinforced concrete, Cement and Concrete Research, 42 (20I2) I, Pp. I24-I33

[18] Carević, I., Banjad Pečur, I., Štirmer, N.: Utilization of Wood Biomass Ash (WBA) in the Cement Composites, Proceedings of the 2nd International Conference on Bio-based Building Materials \& Ist Conference on Ecological valorisation of Granular and Fibrous materials, Clermont-Ferrand, France, Pp. I96-20I, 2017.

[19] Štirmer, N., Carević, I., Šantek Bajto, J., Kostanić Jurić, K.: Physical Properties of Cement Pastes with Different Wood Biomass Ash Contents, Proceedings of the Ist International Conference on Innovation in Low-Carbon Cement \& Concrete Technology, University College London, 2019.

[20] Štirmer, N., Banjad Pečur, I., Carević, I., Pejić, S., Ninčević, A.: Durability properties of cement composities with wood biomass ash, Proceedings of the 4th International Conference on Service Life Design for Infrastructures (SLD4), RILEM Publications S.A.R.L., Delft, pp. 479-488, 2018.

[2I] Tironi, A., Castellano, C. C. , Bonavetti, V. L. ,Trezza, M. A., Scian, A. N. , Irassar, E. F.: Kaolinitic calcined clays - Portland cement system: Hydration and properties, Construction and Building Materials, 64 (2014), pp. 2I5-22I

[22] Antoni, M., Rossen,J., Martirena, F.,Scrivener, K.: Cement substitution by a combination of metakaolin and limestone, Cement and Concrete Research, 42(20I2) I2, Pp. I579-I589

[23] Gao,Y., De Schutter, G.,Ye, G. Huang, H. ,Tan, Z. ,Wu, K.: Characterization of ITZ in ternary blended cementitious composites: Experiment and simulation, Construction and Building Materials $4 \mathrm{I}$ (20I3), Pp. 742-750

[24] Štirmer, N.; Carević, I.; Serdar, M.; Ukrainczyk, N.; Koenders, E.; Šegon, V.: Characterisation of wood biomass ash, Report on project TAREC2, Croatian Science Foundation, University of Zagreb Faculty of Civil Engineering, 2018.

[25] De Weerdt, K., Ben Haha, M., Le Saout, G., Kjellsen, K. O., Justnes,H., Lothenbach, B.: Hydration mechanisms of ternary Portland cements containing limestone powder and fly ash, Cement and Concrete Research, 4 I (20I I) 3, pp. 279-29I

[26] Hajjaji, M., Mleza,Y.: Hydrated burnt clay-lime mixes: Effects of curing time and lime addition,Applied Clay Science, I0I (20I4), doi: I0.I0I6/j.clay.20I4.07.033

[27] Ambroise, J., Murat, M., Pera, J.: Hydration reaction and hardening of calcined clays and related minerals. IV. Experimental conditions for strength improvement on metakaolinite minicylinders, Cement and Concrete Research, I5 (1985) C, pp. 83-88 
[28] Scrivener, K. L. , John, V. M., Gartner, E. M.: Eco-efficient cements: Potential, economically viable solutions for a low-CO2, cement- based materials industry, Paris, 2016.

[29] Ito, A. ,Wagai, R.: Global distribution of clay-size minerals on land surface for biogeochemical and climatological studies, Scientific Data, 4 (2017), doi: 10.1038/sdata.2017.103

[30] Provis, J., Van Deventer, J.: Alkali activated materials, State of the Art Report, Rilem TC 224-AAM, 2014.

[3I] He, J. , Jie, Y., Zhang, J., Yu, Y., Zhang, G.: Synthesis and characterization of red mud and rice husk ashbased geopolymer composites, Cement and Concrete Composites, 37 (2013), pp. I08-II8

[32] Myers, R. J., Bernal, S. A. , Provis, J. L.: Phase diagrams for alkali-activated slag binders, Cement and Concrete Research., 95 (2017), pp. 30-38

[33] Komnitsas, K., Zaharaki, D., Perdikatsis,V.: Geopolymerisation of low calcium ferronickel slags, Journal of Materials Science, 42 (2007) 9, pp. 3073-3082

[34] Zhang, Z., Wang, H., Zhu, Y., A. Reid, A., Provis, J. L., Bullen, F.: Using fly ash to partially substitute metakaolin in geopolymer synthesis, Applied Clay Science, 88-89 (2014), pp. 194-201

[35] Vladić Kancir, l.: Optimisation of alkali-activated binders based on locally available materials, Master thesis, Faculty of Civil Engineering, University of Zagreb, 2018.

[36] World's first public building with structural Geopolymer Concrete, https://www.geopolymer.org/ news/worlds-first-public-building-with-structural-geopolymer-concrete/, 30.10.20I3.

[37] Juenger, M. C. G., Winnefeld, F., Provis, J. L., Ideker, J. H.:Advances in alternative cementitious binders, Cement and Concrete Research, 4I (200I) I2, pp. I232-1243

[38] Hargis, C.W., Telesca, A., Monteiro, P. J. M.: Calcium sulphoaluminate (Ye'elimite) hydration in the presence of gypsum, calcite, and vaterite, Cement and Concrete Research, 65 (2014), pp. I5-20

[39] Chen, I. A., Hargis, C. W., Juenger, M. C. G.: Understanding expansion in calcium sulphoaluminatebelite cements, Cement and Concrete Research, 42 (20I2), pp. 5I-60

[40] Martin, L. H. J., Winnefeld, F., Tschopp, E., Miller, C. J., Lothenbach, B.: Influence of fly ash on the hydration of calcium sulphoaluminate cement, Cement and Concrete Research., 95 (2017), pp. 152 163

[4I] Anić-Božić, A.: Mechanical, durability and deformation properties of concrete based on calcium sulphoaluminate cement, Master thesis, Faculty of Civil Engineering, University of Zagreb, 2018.

[42] Bjegović, D., Baričević, A., Štirmer, N., Carević, I., Banjad Pečur, I.: Innovative Construction Products: Drivers of Sustainable Engineering, 2019 (unpublished work)

[43] Milovanović, B., Štirmer, N., Carević, I.,Baričević, A.: Wood biomass ash as a raw material in the concrete industry, Gradjevinar 7 I (2019) 6, pp.505-5I4

[44] Anton, Á. D., Klebercz, O., Magyar, Á., Burke, I. T., Jarvis, A. P., Gruiz, K., Mayes, W. M.: Geochemical recovery of the Torna-Marcal river system after the Ajka red mud spill, Hungary, Environmental Science: Processes \& Impacts, 16 (20I4) I2, pp. 2677-2685

[45] Carević, I., Serdar, M., Štirmer, N. Ukrainczyk, N.: Preliminary screening of wood biomass ashes for partial resources replacements in cementitious materials, Journal of Cleaner Production 229 (2019), PP. $1045-1064$

[46] Rosković, R., Bjegović, D.: Role of mineral additions in reducing CO_2 emission, Cement and Concrete Research, 35 (2005) 5, pp. 974-978 
[47] Lakušić, S., Bjegović, D., Haladin, I., Baričević,A., Serdar, M. RUCONBAR - innovative noise protection solution made of recycled waste tyres, Mechanics, Transport, Communications, 3 (20II), X-76

[48] Bjegović, D., Serdar, M., Oslaković, I. S.,Jacobs, F.,Beushausen, H.,Andrade, C., Monteiro,A.V., Paulini, P., Nanukuttan, S.:Test Methods for Concrete Durability Indicators - Performance-Based Specifications and Control of Concrete Durability, State-of-the-Art Report RILEMTC 230-PSC, Springer, 20I5, pP. $5 \mathrm{I}-105$

[49] Serdar, M., Peric,V., Bjegovic, D.: Compliance assessment of durability indicators on new Port of Gazenica, Performance-based approaches for concrete structures, Cape Town, 2016.

[50] Breitenbücher, R.:Revision of EN 206-I: what will be modified?, XVI ERMCO Congress, Verona, 2012.

[5I] DURSAAM, The PhD Training Network on Durable, Reliable and Sustainable Structures with AlkaliActivated Materials, http://www.dursaam.ugent.be/index.php, 20.12.2018.

[52] Serdar, M.,Poyet, S., L'Hostis, V., Bjegović, D.: Carbonation of low-alkalinity mortars: Influence on corrosion of steel and on mortar microstructure, Cement and concrete research - including Advanced cement based materials, I0I (20I7), pp. 33-45

[53] Serdar, M.,Bjegović, D., Štirmer, N., Banjad Pečur, I.: Alternative binders for concrete: opportunities and challenges, GRADEVINAR, 7I (2019) I0, https://doi.org/I0.14256/JCE.2729.20I9 